\title{
The impact of anesthetic techniques on breast cancer recurrence: a systematic review of clinical evidence
}

\author{
Aline Tenório Dourado1* (ㄹ, Amanda Vasconcelos de Albuquerque ${ }^{1}$ (1), \\ Dayse Figueiredo Ribeiro de Sena ${ }^{1}$, José Lamartine de Andrade Aguiar ${ }^{1}$
}

\section{ABSTRACT}

Introduction: Surgery is the most effective treatment for breast cancer; however, several factors can impair the immune system during the perioperative period, including the anesthetic technique. Since metastasis is the leading cause of death, one of the treatment pillars is to prevent cancer progression. This systematic review will focus on the prospective clinical evidence available on anesthesia's role in favoring breast cancer recurrence. Methods: The Cochrane Library, Medline, Embase, LILACs, and Web of Science were electronically searched from inception through December 2020 for randomized controlled trials assessing the association of postoperative recurrence and survival with the use of regional anesthesia, opioids, anesthetic adjuncts, and general anesthesia during surgical resection of breast cancer. In total, 711 articles were retrieved. After title and abstract screening and full-text reviews, five randomized controlled trials were selected. Results: Two studies compared inhalation anesthesia with total intravenous anesthesia, while three compared general anesthesia with regional anesthesia and analgesia. There was no significant association between the anesthetic technique and local recurrence, metastasis, or survival. Conclusion: This systematic review did not find an association between the type of anesthesia performed and a higher breast cancer recurrence rate. Up to this time, there is no clinical evidence to support a specific anesthetic technique for malignant breast tumor resection surgeries.

KEYWORDS: breast neoplasms; recurrence; anesthesia.

\section{INTRODUCTION}

Breast cancer is the most commonly diagnosed cancer among women globally, with 1.7 million diagnoses every year ${ }^{1}$ and second in line for the most common cause of cancer-related death ${ }^{2}$. Surgery resection treats a large number of malignant tumors; breast cancer is no exception. Early detection of localized or regional breast cancer can procure a 99\%4-85\% 5-year survival rate $^{3}$, with $97 \%$ of women in stages I or II experiencing surgery ${ }^{4}$. Therefore, perioperative management may interfere with oncological outcomes.

Several risk factors impair the immune system during the perioperative period ${ }^{5}$. Pain, blood transfusion, hypothermia, and anesthetic technique cause immunosuppression, allowing cancerous cells to migrate to distant organs ${ }^{6}$ - even surgical manipulation can release micrometastasis into the circulation, along with the acute inflammatory response that extensive surgery entails?
Metastasis is the major cause of death in breast cancer patients, with a $30 \%$ incidence rate ${ }^{8}$ therefore, preventing recurrence is of paramount importance. A new era of research has emerged in the anesthesia field. Each anesthetic technique affects cancer cells in a particular way. Regional anesthesia reduces surgical stress, inflammatory response, and opioid consumption-11. Local anesthetics (LAs) have shown antiproliferative and cytotoxic effects against in vitro $^{12}$ tumor cells. Sevoflurane suppresses the immune system by decreasing Natural Killer (NK) cells' activity, promoting T-lymphocyte apoptosis and increasing pro-inflammatory cytokines $^{13-15}$. Opioids have a more complex role on cancer recurrence $^{16}$ : a low dose can elicit tumor growth via angiogenesis and down-regulation of the immune response, while high concentrations may curb tumor growth. The opioid receptors $\kappa$ and $\mu$ act divergently, with the former promoting and the latter inducing a pro-inflammatory response ${ }^{17}$.

${ }^{1}$ Universidade Federal de Pernambuco - Recife (PE), Brazil.

*Corresponding author: aline.dourado@ufpe.br

Conflict of interests: nothing to declare.

Funding: Coordenação Aperfeiçoamento de Pessoal de Nível Superior (CAPES).

Received on: 03/18/2021. Accepted on: 06/09/2021. 
A myriad of retrospective studies suggests that volatile anesthetics and opioid anesthesia promote breast cancer recurrence compared to propofol-based and regional anesthesia ${ }^{18-20}$. Exadaktylos et al. ${ }^{18}$ reported that women had a significantly lower risk of cancer recurrence if submitted to a combination of propofol and thoracic paravertebral block (TPVB) compared to balanced general anesthesia (GA) with sevoflurane and opioids. However, the anesthetic technique of choice for mastectomies is still debatable.

This systematic review focused on the clinical evidence available on the role of anesthesia regarding breast cancer recurrence. To the extent of our knowledge, it was the first to compare only prospective randomized control trials. We described the data and critically analyzed randomized clinical trials on the use of regional anesthesia, opioids, anesthetics adjuncts, and GA in patients undergoing breast cancer resection.

\section{METHODS}

This systematic review was conducted according to the Cochrane Handbook for Systematic Reviews and Interventions ${ }^{21}$ and the Preferred Reporting Items for Systematic Reviews and Metaanalyses (PRISMA) ${ }^{22}$. The study protocol was published on Open Science Framework,

\section{Search strategy}

We conducted an electronic search of the following databases (from inception through December 2, 2020): Cochrane Library and Cochrane Trials Register, Medline, Embase, LILACs, and Web of Science; no language limitation was enforced. Search terms included: "Breast Cancer", "Anesthetic Technique" or "Regional Anesthesia" or "General Anesthesia", "Propofol" or "Sevoflurane", "Disease Free Survival" or "Recurrence" or "Metastasis". The complete list of search terms is attached in the online Appendix 1. Manually, we performed a thorough search within oncological and anesthesia society websites, annals of congresses, and articles' reference lists. Ongoing clinical trials were also assembled by searching the combination "breast neoplasms" at https:// clinicaltrials.gov/23.

\section{Study selection and data extraction}

The inclusion criteria were threefold: randomized controlled clinical trials (RCT), surgery for resection of malignant breast tumor in female over 18 years old, and three possible interventions' scenarios - comparing the use of regional anesthesia, either isolated or combined to general anesthesia, with general anesthesia; comparing volatile anesthesia with total intravenous anesthesia; comparing opioid-free anesthesia with opioids. Studies depicting metastatic disease were excluded. The primary outcome was postoperative cancer recurrence, defined as locoregional recurrence and distant metastasis.
The secondary outcomes were overall survival and recurrence-free survival.

Two of the authors (A.D., D.S.) independently assessed titles and abstracts for admittance into this review. If any divergence of judgment were manifested, a third author (A.A.) would settle. The data were extracted in a standardized way through an electronic form. Apart from measured outcomes and types of interventions, other extracted data included study-related information, such as author, year of publication, sample, follow-up time, and conclusions. Given methodological diversity and statistical heterogeneity, a meta-analysis was not conducted. Instead, a systematic review of the applicable clinical evidence was completed.

\section{Risk of bias}

We covered six domains for assessing the risk of individual bias ${ }^{24}$ : selection bias, performance bias, detection bias, attrition bias, reporting bias, and others. A high risk of bias is considered when the studies fall out of these criteria. Two authors independently appraised these risks for the breast cancer recurrence outcome, which are summarized in Figure 1.

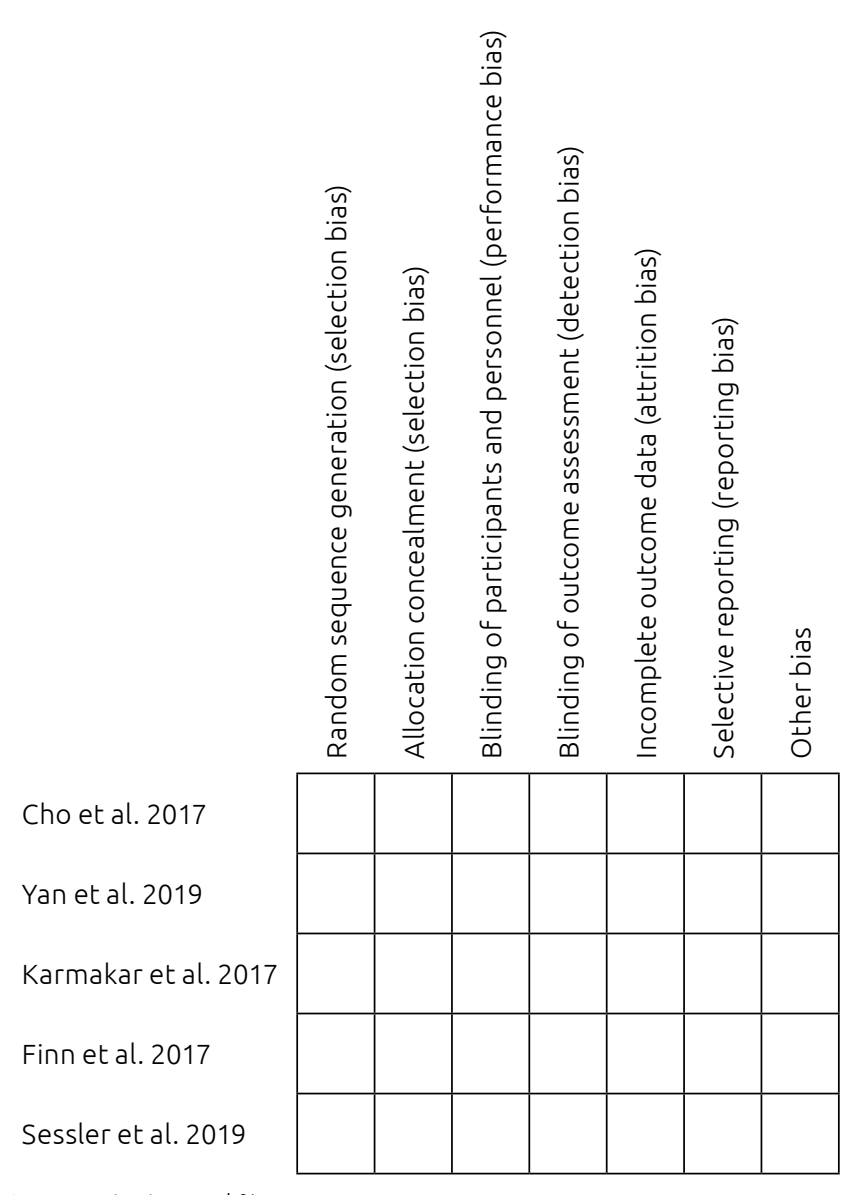

Source: Higgins et al. ${ }^{24}$.

Figure 1. Risk of bias summary. 


\section{RESULTS}

The electronic and manual search found 899 studies, 711 of them eligible for title and abstract review. Six hundred and seventytwo studies were deemed irrelevant, while 39 were singled out for full-text reading and quality assessment. Lastly, five clinical trials were selected for data extraction (Figure 2).

Two studies compared the association of inhalation anesthesia and total intravenous anesthesia (TIVA) (Table 1) on cancer

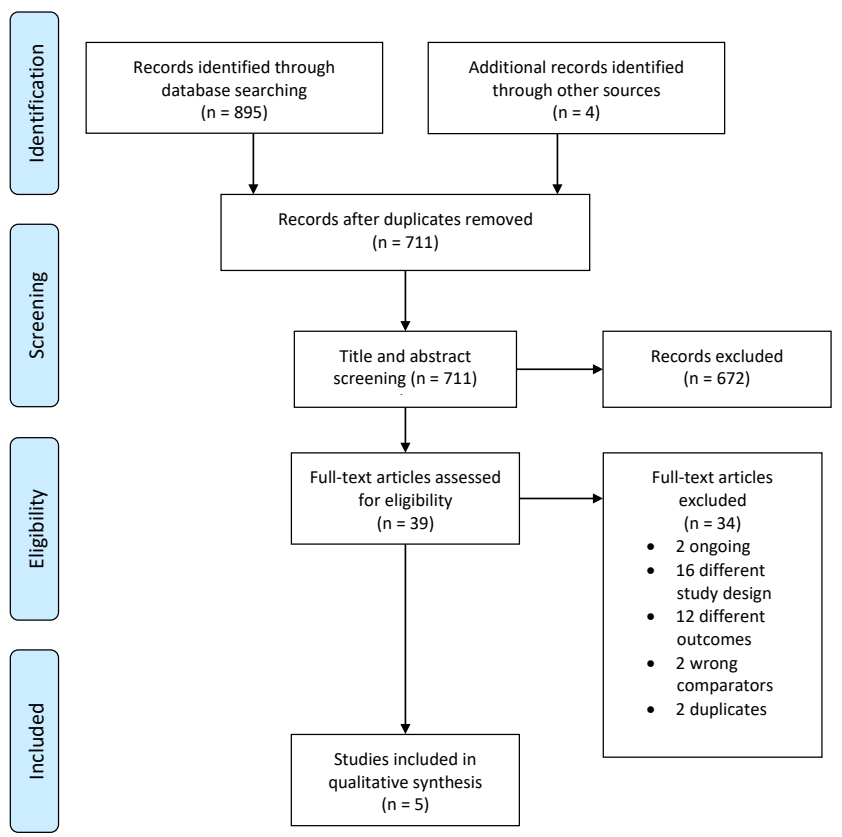

Source: Shamseer et al. ${ }^{22}$.

Figure 2. PRISMA flow diagram. recurrence rates, metastasis, recurrence-free survival (RFS), and overall survival (OS). Both included patients with breast cancer stage 0 -III, and the type of surgery performed varied from breastconserving surgery to radical mastectomy, with no significant difference between the groups. Cho et al. ${ }^{25}$ followed 48 women for two years to find that only one patient in the sevoflurane-fentanyl (SEVO) group had a recurrence in the contralateral breast without statistical significance. Yan et al. ${ }^{26}$ also investigated short-term cancer recurrence in 80 women for the same amount of time. The twoyear RFS rate in the SEVO and TIVA groups for the first and second studies, respectively, averaged $89.5 \%$ and $97.6 \%(p=0.138)$ while the two-year OS rate did $92.8 \%$ and $100 \%(p=0.182)$.

The other three studies investigated cancer recurrence by comparing general anesthesia with regional anesthesia and analgesia (Table 2). Finn et al. ${ }^{27}$ followed 54 women for five years - all underwent mastectomy with balanced GA and thoracic paravertebral block (TPVB), but, for 72 hours after surgery, one group received a perineural infusion of ropivacaine while the other received saline (placebo). No significant association between the anesthesia technique and cancer recurrence was observed. Karmakar et al. ${ }^{28}$ followed 173 women for five years after a modified radical mastectomy and used a similar method of a continuous TPVB. The women were randomized into three groups: control, perineural infusion with saline (placebo), and perineural infusion with ropivacaine; all of them received total intravenous GA with propofol. Each group incidences of local cancer recurrence, metastasis, and all-cause mortality were $2.3 \%$ (95\%CI 0.7-5.4\%), 7.9\% (95\%CI 4.6-12.6\%), and 6.8\% (95\%CI 3.6-11.2\%), respectively. These studies did not discriminate in which breast cancer stage the patients were admitted.

Table 1. Summary of trials comparing total intravenous general anesthesia versus balanced general anesthesia.

\begin{tabular}{|c|c|c|c|c|c|c|c|c|c|c|c|}
\hline Author & Year & $\begin{array}{l}\text { Study } \\
\text { design }\end{array}$ & $\begin{array}{l}\text { Tumor } \\
\text { stage }\end{array}$ & $\begin{array}{l}\text { Type of } \\
\text { surgery }\end{array}$ & Intervention & \multicolumn{2}{|c|}{ Groups } & Outcome & $\begin{array}{c}\text { Follow-up } \\
\text { time }\end{array}$ & Conclusion & Observations \\
\hline \multirow[b]{2}{*}{$\begin{array}{l}\text { Cho } \\
\text { et al. } .^{25}\end{array}$} & \multirow[b]{2}{*}{2017} & \multirow[b]{2}{*}{ RCT } & \multirow[b]{2}{*}{$0-111$} & \multirow[b]{2}{*}{$\begin{array}{c}\text { Partial } \\
\text { mastectomy, } \\
\text { total } \\
\text { mastectomy, } \\
\text { radical } \\
\text { mastectomy }\end{array}$} & \multirow[b]{2}{*}{$\begin{array}{l}\text { TIVA vs GA } \\
\text { with volatile } \\
\text { anesthetic }\end{array}$} & $\begin{array}{c}\text { TIVA } \\
(n=24)\end{array}$ & $\begin{array}{l}\text { SEVO } \\
(n=24)\end{array}$ & \multirow[b]{2}{*}{$\begin{array}{l}\text { Incidence } \\
\text { of cancer } \\
\text { recurrence } \\
\text { and } \\
\text { metastasis }\end{array}$} & \multirow[b]{2}{*}{2 years } & \multirow{2}{*}{$\begin{array}{c}\text { No } \\
\text { significant } \\
\text { association } \\
\text { between } \\
\text { anesthesia } \\
\text { technique } \\
\text { and } \\
\text { recurrence } \\
\text { was } \\
\text { observed. }\end{array}$} & \multirow[b]{2}{*}{$\begin{array}{l}\text { Both } \\
\text { groups used } \\
\text { remifentanil } \\
\text { and tramadol. }\end{array}$} \\
\hline & & & & & & $\begin{array}{c}\text { Propofol } \\
(\mathrm{TCl})+ \\
\text { Ketorolac } \\
(60 \mathrm{mg})\end{array}$ & $\begin{array}{c}\text { Sevoflurane } \\
\text { (according } \\
\text { to BIS) + } \\
\text { Fentanyl (50 } \\
\text { mcg) }\end{array}$ & & & & \\
\hline \multirow[b]{2}{*}{$\begin{array}{l}\text { Yan } \\
\text { et al. }{ }^{26}\end{array}$} & \multirow[b]{2}{*}{2019} & \multirow[b]{2}{*}{$\mathrm{RCT}$} & \multirow[b]{2}{*}{$0-111$} & \multirow[b]{2}{*}{$\begin{array}{c}\text { BCS, } \\
\text { mastectomy } \\
\text { with or } \\
\text { without } \\
\text { axillary } \\
\text { lymph node } \\
\text { dissection }\end{array}$} & \multirow[b]{2}{*}{$\begin{array}{l}\text { TIVA vs GA } \\
\text { with volatile } \\
\text { anesthetic }\end{array}$} & $\begin{array}{c}\text { TIVA } \\
(n=42)\end{array}$ & $\begin{array}{l}\text { SEVOO } \\
(n=38)\end{array}$ & \multirow[b]{2}{*}{$\begin{array}{l}\text { Incidence } \\
\text { of cancer } \\
\text { recurrence, } \\
\text { RFS and OS }\end{array}$} & \multirow[b]{2}{*}{2 years } & \multirow{2}{*}{$\begin{array}{c}\text { No } \\
\text { significant } \\
\text { association } \\
\text { between } \\
\text { anesthesia } \\
\text { technique } \\
\text { and } \\
\text { recurrence } \\
\text { was } \\
\text { observed. }\end{array}$} & \multirow[b]{2}{*}{$\begin{array}{l}\text { Both } \\
\text { groups used } \\
\text { fentanyl and } \\
\text { flurbiprofen. }\end{array}$} \\
\hline & & & & & & $\begin{array}{c}\text { Propofol } \\
3-6 \mathrm{mg} / \\
\mathrm{kg} / \mathrm{h}\end{array}$ & $\begin{array}{c}\text { Sevoflurane } \\
1.5-2 \% \\
\text { (according } \\
\text { to BIS) }\end{array}$ & & & & \\
\hline
\end{tabular}

RCT: randomized controlled trial; TCI: target control infusion; TIVA: total intravenous anesthesia; SEVO: Sevoflurane; BIS: Bispectral index; RFS: recurrence free survival; OS: overall survival; BCS: breast conserving sugery. 


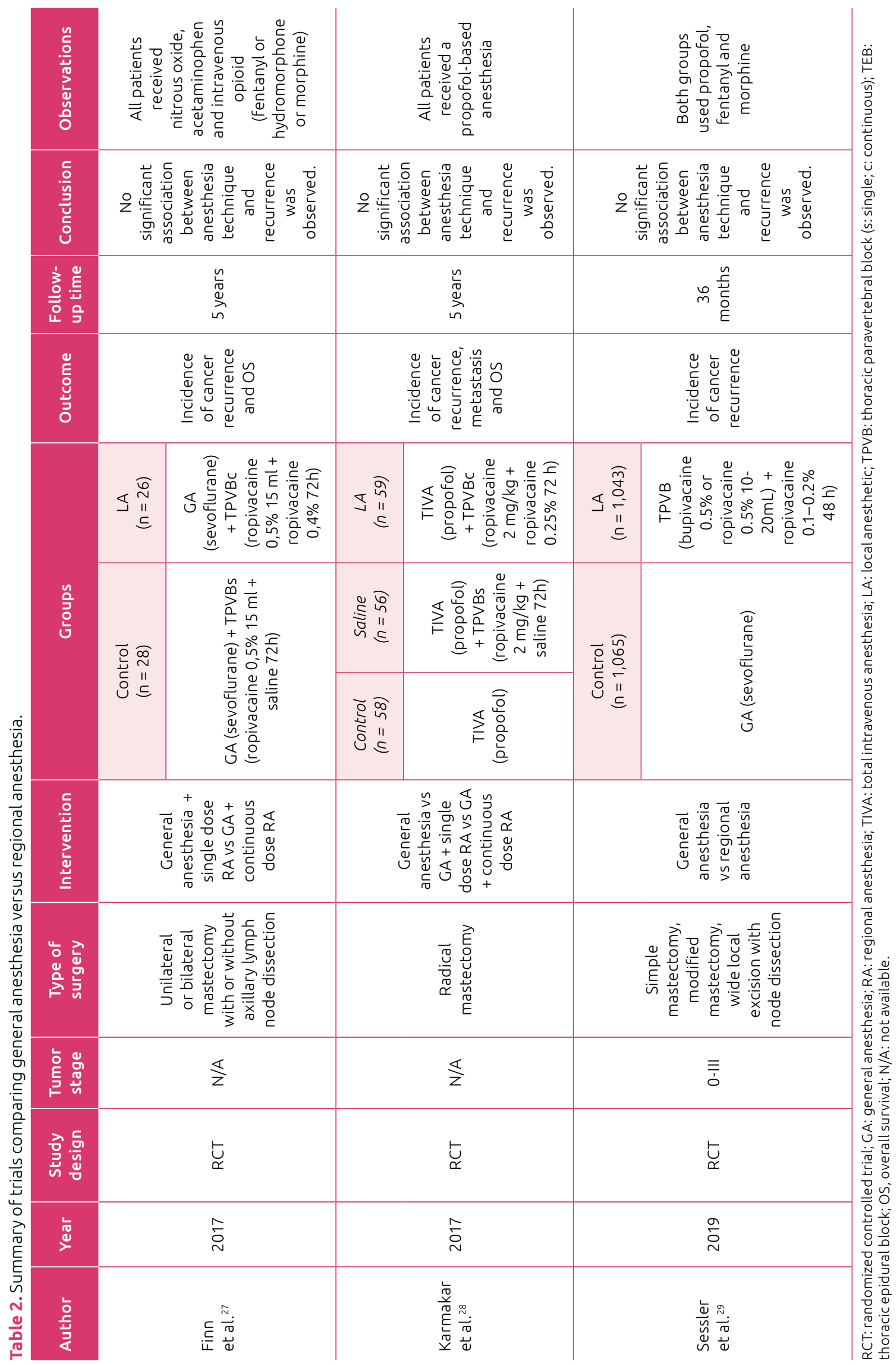


The third study is a multicenter, prospective, randomized trial conducted by Sessler et al. ${ }^{29}$. Over two thousand women, initially classified as breast cancer stage 0 -III, were accompanied for a median follow-up of 36 (IQR 24-49) months and divided into two groups: regional anesthesia-analgesia $(n=1,043)$ and general anesthesia and opioid analgesia $(n=1,065)$. The first group received a thoracic epidural or a paravertebral block with a continuous catheter infusion of local anesthetic for postoperative analgesia. In the second group, anesthesia was maintained with sevoflurane, and the patients received morphine sulfate at the end of the surgery. The groups reported $102(10 \%)$ against $111(10 \%)$ recurrences, respectively ( $\mathrm{HR}=0.97,95 \% \mathrm{CI} 0.74-1.28 ; \mathrm{P}=0.84$ ), indicating that regional anesthesia did not reduce breast cancer recurrence.

A meta-analysis was not conducted due to the diverseness in general anesthesia techniques, local anesthetics used for TPVB, and tumor staging permeating each study.

\section{DISCUSSION}

Our research showed no significant statistical association between anesthetic technique and higher breast cancer recurrence rate. Since our review was limited to randomized clinical trials, only five studies could be considered, although a few ongoing clinical trials may publish results in the following years (Table 3).

We divided our findings into two groups: intravenous anesthesia versus volatile anesthesia and general anesthesia (GA) versus GA combined with regional techniques (Table 1). In the first group, neither study reported intervention-related benefits.

Table 3. Summary of ongoing clinical trials registered on Clinicaltrials.gov.

\begin{tabular}{|c|c|c|}
\hline Trial number & Study Title & Interventions \\
\hline NCT03109990 & $\begin{array}{c}\text { Impact of } \\
\text { Dexmedetomidine } \\
\text { on Breast Cancer } \\
\text { Recurrence After } \\
\text { Surgery }\end{array}$ & $\begin{array}{l}\text { •Drug: } \\
\text { Dexmedetomidine } \\
\text { •Drug: Saline }\end{array}$ \\
\hline NCT03941223 & $\begin{array}{l}\text { Regional Anesthesia } \\
\text { for Breast Surgery }\end{array}$ & $\begin{array}{c}\text {-Procedure: PECSII } \\
\text { and paravertebral } \\
\text { blocks }\end{array}$ \\
\hline NCT01204242 & $\begin{array}{c}\text { IV Lidocaine } \\
\text { for Patients } \\
\text { Undergoing Primary } \\
\text { Breast Cancer } \\
\text { Surgery: Effects } \\
\text { on Postoperative } \\
\text { Recovery and Cancer } \\
\text { Recurrence }\end{array}$ & $\begin{array}{l}\text { •Drug: Lidocaine } \\
\text { •Drug: Saline }\end{array}$ \\
\hline NCT03117894 & $\begin{array}{c}\text { PECS-2 for Breast } \\
\text { Surgery }\end{array}$ & -Procedure: PECS-2 \\
\hline
\end{tabular}

PECS2: pectoral nerve block type 2.
This finding contradicts Wigmore et al. ${ }^{30}$, who, in a 2016 retrospective study with over 7,000 cancer patients, reported an approximately $50 \%$ higher mortality rate for volatile anesthesia against intravenous anesthesia, with an adjusted hazard ratio of 1.46 (1.29 to 1.66 ).

Cho et al. ${ }^{25}$ compared two groups with different anesthetic techniques and analgesia: a propofol-ketorolac group (TIVA) and a sevoflurane-fentanyl group (SEVO), investigating the effect of these techniques in the cytotoxicity of natural killer cells and tumor recurrence up to two years after surgery. Cancer metastasis did not occur in either group, in spite of different drug properties. Propofol has cyclooxygenase (COX-2) inhibiting activity, which reduces the production of prostaglandin E2 (PGE2), a mediator of pain and inflammation ${ }^{31}$. Ketorolac also impedes prostaglandin synthesis via the inhibition of the COX enzyme, above its antitumor and anti-angiogenic properties ${ }^{32}$. Volatile anesthetics and fentanyl, though, suppress NK cells and T lymphocytes ${ }^{33,34}$.

Pain causes immunosuppression ${ }^{35}$; however, since both groups had a similar analgesic efficacy, the authors could eliminate it as a contributing factor. Pain scores were assessed using an 11-point numerical rating scale (NRS) at 30 minutes, 6 hours, $24 \mathrm{~h}$, and $48 \mathrm{~h}$ postoperatively. If the patients complained of an NRS $\geq 4$ pain, ketorolac and propacetamol were given to the TIVA group and fentanyl to the SEVO group. Since both groups received different analgesic drugs, the authors could not discriminate each drug's effects on inflammatory response. Another limitation of the study was that all patients received remifentanil intraoperatively and tramadol for postoperative pain control - even though they are not considered immunosuppressive drugs and the doses were equivalent between the groups ${ }^{36,37}$, we cannot exclude their opioid effect.

Yan et al. ${ }^{26}$ had a short-term recurrence rate of breast cancer in five (6.3\%) patients, four SEVO and one TIVA, during 28 months of follow-up. Two deaths were observed, both in the volatile group. No difference was found between RFS ( $p=0.953)$ and OS $(p=0.281)$ between the two anesthetic techniques. Propofol was used for anesthetic induction in both groups, and fentanyl and flurbiprofen were given to all patients to provide postoperative analgesia. Those interventions could make it difficult to differentiate the individual properties of sevoflurane and propofol in the immune response. However, the study aimed to compare different anesthetic techniques rather than just different drugs.

In both Cho's and Yan's studies, we found puzzling elements and could not observe benefits from either anesthetic technique. Besides, the short-term RFS of breast cancer was elevated ${ }^{38}$, which would require a large sample and a longer follow-up to detect any significant difference.

Forget et al. ${ }^{39}$ had already suggested that non-steroidal antiinflammatory drugs (NSAIDs) given shortly before surgery produce antitumor effects. Fentanyl has also demonstrated antitumor properties by inhibiting cancer cell migration and invasion ${ }^{40}$; 
however, in a large Danish cohort population study, opioid use showed no clinically significant association with breast cancer recurrence $e^{41}$. Thus, the effects of opioids on tumor growth and metastasis are complex and controversial: they may play a beneficial role, but it depends on drug concentration, duration of exposure, and even cancer type ${ }^{16,42}$.

In 2006, the first study to describe a positive relationship between regional anesthesia and breast tumor propagation, by Exadaktylos et al. ${ }^{18}$, showed the recurrence rate for the sevoflurane-fentanyl group as four times higher than the propofol-paravertebral block group. On the other hand, Kairaluoma et al. ${ }^{43}$, in 2016, published a similar retrospective study following 86 women for 12 years; the results did not demonstrate any anti-metastatic effect of perioperative regional anesthesia.

Our second group of studies, which analyzed regional techniques, culminated in findings analogous to Kairaluoma et al's. Karmakar et al. ${ }^{28}$ compared TIVA with GA combined with TPVB and a third group that used postoperative transcatheter analgesia. There was no difference in the risk of local cancer recurrence, metastasis, or all-cause mortality between the groups $(\mathrm{p}=0.79$, $p=0.91$, and $p=0.13$, respectively). When compared to the group which received only GA, the risk of local recurrence or metastasis agreed with that for patients in the GA plus single-TPVB group ( $\mathrm{HR}=1.11,95 \% \mathrm{CI} 0.32-3.83)$ or the GA plus continuous-TPVB group ( $\mathrm{HR}=0.79,95 \% \mathrm{CI} 0.21-2.96)$.

Since all patients received total intravenous anesthesia with propofol, it is questioned whether this could camouflage the regional anesthesia technique's anti-inflammatory perk. As explained earlier, propofol has numerous documented positive effects on the immune system function ${ }^{14,31,44}$, so that the TIVA components may have conferred this immunoprotective benefit. In contrast, using a single general anesthesia technique helped to evaluate how regional anesthesia affected the recurrence rate.

Finn et al..$^{27}$ concluded that adding a continuous ropivacaine infusion to a single-injection paravertebral block in the immediate postoperative period did not decrease the post-mastectomy cancer recurrence risk. Five out of 54 (9.3\%) patients suffered from recurrence: three among those in the ropivacaine group $(11.5 \%)$ and two in the saline group $(7.1 \% ; \mathrm{p}=0.92)$. Nevertheless, we should also consider that single-injection ropivacaine was administered to all patients, which might have decreased surgical stress in both treatment groups - ropivacaine can provide 8-16 hours of analgesia. Therefore, albeit not always an obvious choice, regional anesthesia is a technique with proven benefits; with the TPVB comes less chronic pain and better postoperative physical and mental performance ${ }^{45}$.

Sessler et al. ${ }^{29}$ was a much-expected multicenter trial. A large sample and well-designed study, it proved the irrelevance of the regional anesthetic technique in attaining less tumoral occurrence. Nonetheless, there is space for reservations, as has already been discussed ${ }^{46-49}$. Firstly, anesthetic techniques overlapped, with the concurrent use of fentanyl, propofol, and morphine in all patients and the supplementation of sevoflurane in $17 \%$ of the patients from the paravertebral block group. This combined use of opioids and volatile anesthetic with the regional technique might have interfered with its benefit. Secondly, the average follow-up of 36 months can be considered a short time to assess tumor recurrence. Finally, better screening and superior protocol regimens have decreased breast cancer mortality rates over the last decade ${ }^{50}$, meaning the clinical treatment of the disease itself has evolved ${ }^{51}$ during the total general study period of 12 years.

The temporary immune changes caused by anesthetic drugs do not seem to bring long-term repercussions. Despite the paucity of relevant randomized controlled trials, where just one avails a high level of evidence, our qualitative analyses did not find an association between the type of anesthesia performed and the prognosis in breast cancer patients. Neither regional nor total intravenous anesthetic techniques showed significantly superior outcomes when compared to general anesthesia.

Our research's primary limitations were the narrow set of applicable studies, the significant heterogeneity, the small sample size and short follow-up time from some trials, and the high or unclear risk of bias from most included studies. This type of review suffers from difficulty to standardize in order to reduce bias. It is impossible to blind the anesthesiologist who will administer distinct techniques. Besides, each trial adopted different doses and concentrations, and the disease itself bears multiple stages. The stage and grade of the tumors and the surgical management variables presented a good distribution among the study groups, but most women were diagnosed in the early stages, which naturally translates to fewer recurrence rates ${ }^{3}$. Due to this low incidence of recurrence, the validation of the findings might prove difficult, even with significant statistical differences. There are yet other questions that may raise bias for this type of controlled trial: does breast cancer surgery stress is enough to cause immunosuppression? Does the natural evolution of anti-cancer therapies inhibit the in-vitro-proved ${ }^{52,53}$ harmful effects of anesthetics? Therefore, we suggest choosing the best available technique, considering patient comorbidities and particularities.

\section{CONCLUSION}

This review did not find an association between the type of anesthesia performed and the long-term prognosis in patients with breast cancer. It points out to no clinical evidence currently supporting a specific anesthetic technique for malignant breast tumor resection surgeries. However, the scarcity of high-quality randomized clinical trials on the subject, with larger samples and longer follow-up times demands further research. 


\section{AUTHORS' CONTRIBUTION}

A.D.: conceptualization, investigation, methodology, data acquisition, formal analysis, writing - first draft, writing - review \& editing; A.A.: conceptualization, investigation, methodology, data acquisition, formal analysis, writing - first draft; D.S.: conceptualization, investigation, methodology, data acquisition, formal analysis, writing - review \& editing; J.L.A.: conceptualization, methodology, formal analysis, writing - review \& editing.

\section{REFERENCES}

1. Ferlay J, Soerjomataram I, Dikshit R, Eser S, Mathers C, Rebelo $\mathrm{M}$, et al. Cancer incidence and mortality worldwide: sources, methods and major patterns in GLOBOCAN 2012. Int J Cancer. 2015;136(5):E359-86. https://doi.org/10.1002/ijc.29210

2. Ghoncheh $\mathrm{M}$, Pournamdar $\mathrm{Z}$, Salehiniya $\mathrm{H}$. Incidence and Mortality and Epidemiology of Breast Cancer in the World. Asian Pac J Cancer Prev. 2016;17(S3):43-6. https://doi. org/10.7314/apjcp.2016.17.s3.43

3. Noone AM, Howlader N, Krapcho M, Miller D, Brest A, Yu M, et al. (eds.). Cancer Statistics Review, 1975-2015 - SEER Statistics. Bethesda: National Cancer Institute; 2018.

4. Miller KD, Siegel RL, Lin CC, Mariotto AB, Kramer JL, Rowland JH, et al. Cancer treatment and survivorship statistics, 2016. CA Cancer J Clin. 2016;66(4):271-89. https://doi.org/10.3322/ caac. 21349

5. Eden C, Esses G, Katz D, DeMaria Jr. S. Effects of anesthetic interventions on breast cancer behavior, cancer-related patient outcomes, and postoperative recovery. Surg Oncol. 2018;27(2):266-74. https://dx.doi.org/10.1016\%2Fj. suronc.2018.05.001

6. Horowitz M, Neeman E, Sharon E, Ben-Eliyahu S. Exploiting the critical perioperative period to improve long-term cancer outcomes. Nat Rev Clin Oncol. 2015;12(4):213-26. https://doi. org/10.1038/nrclinonc.2014.224

7. Neeman E, Ben-Eliyahu S. Surgery and stress promote cancer metastasis: new outlooks on perioperative mediating mechanisms and immune involvement. Brain Behav Immun. 2013;30(Suppl.):S32-40. https://doi.org/10.1016/j.bbi.2012.03.006

8. O'Shaughnessy J. Extending survival with chemotherapy in metastatic breast cancer. Oncologist. 2005;10(Suppl. 3):20-9. https://doi.org/10.1634/theoncologist.10-90003-20

9. Weng M, Chen W, Hou W, Li L, Ding M, Miao C. The effect of neuraxial anesthesia on cancer recurrence and survival after cancer surgery: an updated meta-analysis. Oncotarget. 2016;7(12):15262-73. https://doi.org/10.18632/oncotarget.7683

10. Deegan CA, Murray D, Doran P, Moriarty DC, Sessler DI, Mascha E, et al. Anesthetic Technique and the Cytokine and Matrix Metalloproteinase Response to Primary Breast Cancer Surgery. Reg Anesth Pain Med. 2010;35(6):490-5. https://doi. org/10.1097/aap.0b013e3181ef4d05

11. Wu J, Buggy D, Fleischmann E, Parra-Sanchez I, Treschan T, Kurz A, et al. Thoracic paravertebral regional anesthesia improves analgesia after breast cancer surgery: a randomized controlled multicentre clinical trial. Can J Anaesth. 2015;62(3):241-51. https://doi.org/10.1007/s12630-014-0285-8

12. Li R, Xiao C, Liu H, Huang Y, Dilger JP, Lin J. Effects of local anesthetics on breast cancer cell viability and migration. BMC
Cancer. 2018;18(1):666. https://doi.org/10.1186/s12885-0184576-2

13. Ecimovic P, McHugh B, Murray D, Doran P, Buggy DJ. Effects of Sevoflurane on Breast Cancer Cell Function In Vitro. Anticancer Res. 2013;33(10):4255-60.

14. Melamed R, Bar-Yosef S, Shakhar G, Shakhar K, Ben-Eliyahu S. Suppression of Natural Killer Cell Activity and Promotion of Tumor Metastasis by Ketamine, Thiopental, and Halothane, but Not by Propofol: Mediating Mechanisms and Prophylactic Measures. Anesth Analg. 2003;97(5):1331-9. https://doi. org/10.1213/01.ane.0000082995.44040.07

15. Yuki K, Astrof NS, Bracken C, Sulpicio GS, Shimaoka M. Sevoflurane binds and allosterically blocks integrin lymphocyte function-associated antigen-1. Anesthesiology. 2010;113(3):600-9. https://doi.org/10.1097/ aln.0b013e3181e89a77

16. Juneja R. Opioids and cancer recurrence. Curr Opin Support Palliat Care. 2014;8(2):91-101. https://doi.org/10.1097/ spc.0000000000000056

17. Lin X, Wang YJ, Li Q, Hou YY, Hong MH, Cao YL, et al. Chronic high-dose morphine treatment promotes SH-SY5Y cell apoptosis via c-Jun N-terminal kinase-mediated activation of mitochondria-dependent pathway. FEBS J. 2009;276(7):202236. https://doi.org/10.1111/j.1742-4658.2009.06938.x

18. Exadaktylos AK, Buggy DJ, Moriarty DC, Mascha E, Sessler DI. Can anesthetic technique for primary breast cancer surgery affect recurrence or metastasis? Anesthesiology. 2006;105(4):660-4. https://doi.org/10.1097/00000542200610000-00008

19. Lee JH, Kang SH, Kim Y, Kim HA, Kim BS. Effects of propofolbased total intravenous anesthesia on recurrence and overall survival in patients after modified radical mastectomy: A retrospective study. Korean J Anesthesiol. 2016;69(2):126-32. https://doi.org/10.4097/kjae.2016.69.2.126

20. Koonce SL, Mclaughlin SA, Eck DL, Porter S, Bagaria S, Clendenen SR, et al. Breast cancer recurrence in patients receiving epidural and paravertebral anesthesia: a retrospective, case-control study. Middle East J Anaesthesiol. 2014;22(6):567-71.

21. Higgins J, Green S. Cochrane Handbook for Systematic Reviews of Interventions Version 5.1.0 [updated March 2011]. The Cochrane Collaboration. The Cochrane Collaboration; 2011.

22. Shamseer L, Moher D, Clarke M, Ghersi D, Liberati A, Petticrew $\mathrm{M}$, et al. Preferred reporting items for systematic review and meta-analysis protocols (prisma-p) 2015: Elaboration and explanation. BMJ. 2015;350:g7647. https://doi.org/10.1136/bmj. g7647 
23. National Library of Medicine (US). Clinical Trials [Internet]. Bethesda: National Library of Medicine [cited on Dec. 30, 2020]. Available from: https://clinicaltrials.gov

24. Higgins JPT, Altman DG, Gøtzsche PC, Jüni P, Moher D, Oxman $\mathrm{AD}$, et al. The Cochrane Collaboration's tool for assessing risk of bias in randomised trials. BMJ. 2011;343;d5928. https://doi. org/10.1136/bmj.d5928

25. Cho JS, Lee MH, Kim SI, Park S, Park HS, Oh E, et al. The Effects of Perioperative Anesthesia and Analgesia on Immune Function in Patients Undergoing Breast Cancer Resection: a Prospective Randomized Study. Int J Med Sci. 2017;14(10):9706. https://doi.org/10.7150/ijms.20064

26. Yan T, Zhang G-H, Cheng Y-Z, Wu L-X, Liu X-Y, Sun Y-L, et al. Effects of anesthetic technique and surgery on myeloid-derived suppressor cells and prognosis in women who underwent breast cancer surgery: a prospective study. Cancer Manag Res. 2019;11:5513-22. https://doi.org/10.2147/cmar.s183519

27. Finn DM, Ilfeld BM, Unkart JT, Madison SJ, Suresh PJ, Sandhu NPS, et al. Post-mastectomy cancer recurrence with and without a continuous paravertebral block in the immediate postoperative period: a prospective multi-year follow-up pilot study of a randomized, triple-masked, placebo-controlled investigation. J Anesth. 2017;31(3):374-9. https://dx.doi. org/10.1007\%2Fs00540-017-2345-z

28. Karmakar MK, Samy W, Lee A, Li JW, Chan WC, Chen PP, et al. Survival Analysis of Patients with Breast Cancer Undergoing a Modified Radical Mastectomy With or Without a Thoracic Paravertebral Block: a 5-Year Follow-up of a Randomized Controlled Trial. Anticancer Res. 2017;37(10):5813-20. https:// doi.org/10.21873/anticanres.12024

29. Sessler DI, Pei L, Huang Y, Fleischmann E, Marhofer P, Kurz A, et al. Recurrence of breast cancer after regional or general anaesthesia: a randomised controlled trial. Lancet. 2019;394(10211):1807-15. https://doi.org/10.1016/S0140-6736(19)32313-X

30. Wigmore TJ, Mohammed K, Jhanji S. Long-term Survival for Patients Undergoing Volatile versus IV Anesthesia for Cancer Surgery: A Retrospective Analysis. Anesthesiology. 2016;124(1):69-79. https://doi.org/10.1097/ aln.0000000000000936

31. Inada $\mathrm{T}$, Kubo $\mathrm{K}$, Shingu $\mathrm{K}$. Possible link between cyclooxygenase-inhibiting and antitumor properties of propofol. J Anesth. 2011;25(4):569-75. https://doi.org/10.1007/ s00540-011-1163-y

32. Farooqui M, Li Y, Rogers T, Poonawala T, Griffin RJ, Song CW, et al. COX-2 inhibitor celecoxib prevents chronic morphineinduced promotion of angiogenesis, tumour growth, metastasis and mortality, without compromising analgesia. Br J Cancer. 2007;97(11):1523-31. https://dx.doi.org/10.1038\%2Fsj. bjc. 6604057

33. Pirbudak Cocelli L, Ugur MG, Karadasli H. Comparison of effects of low-flow sevoflurane and desflurane anesthesia on neutrophil and T-cell populations. Curr Ther Res Clin Exp. 2012;73(1-2):41-51. https://doi.org/10.1016/j. curtheres.2012.02.005

34. Plein LM, Rittner HL. Opioids and the immune system friend or foe. Br J Pharmacol. 2018;175(14):2717-25. https://doi. org/10.1111/bph.13750
35. Snyder GL, Greenberg S. Effect of anaesthetic technique and other perioperative factors on cancer recurrence. Br J Anaesth. 2010;105(2):106-15. https://doi.org/10.1093/bja/aeq164

36. Cronin AJ, Aucutt-Walter NM, Budinetz T, Bonafide CP, DiVittore NA, Gordin V, et al. Low-dose remifentanil infusion does not impair natural killer cell function in healthy volunteers. Br J Anaesth. 2003;91(6):805-9. https://doi. org/10.1093/bja/aeg273

37. Sacerdote P, Manfredi B, Mantegazza P, Panerai AE. Antinociceptive and immunosuppressive effects of opiate drugs: a structure-related activity study. Br J Pharmacol. 1997;121(4):834-40. https://doi.org/10.1038/sj.bjp.0701138

38. Houze de l'Aulnoit A, Rogoz B, Pincon C, Houze de l'Aulnoit D. Metastasis-free interval in breast cancer patients: Thirtyyear trends and time dependency of prognostic factors. A retrospective analysis based on a single institution experience. Breast. 2018;37:80-8. https://doi.org/10.1016/j. breast.2017.10.008

39. Forget P, Vandenhende J, Berliere M, Machiels J-P, Nussbaum B, Legrand C, et al. Do intraoperative analgesics influence breast cancer recurrence after mastectomy? A retrospective analysis. Anesth Analg. 2010;110(6):1630-5. https://doi. org/10.1213/ane.0b013e3181d2ad07

40. Li A, Xin W, Ma C. Fentanyl inhibits the invasion and migration of colorectal cancer cells via inhibiting the negative regulation of Ets-1 on BANCR. Biochem Biophys Res Commun. 2015;465(3):594-600. https://doi.org/10.1016/j.bbrc.2015.08.068

41. Cronin-Fenton DP, Heide-Jørgensen U, Ahern TP, Lash TL, Christiansen PM, Ejlertsen B, et al. Opioids and breast cancer recurrence: A Danish population-based cohort study. Cancer. 2015;121(19):3507-14. https://doi.org/10.1002/cncr.29532

42. Yardeni IZ, Beilin B, Mayburd E, Alcalay Y, Bessler H. Relationship between fentanyl dosage and immune function in the postoperative period. J Opioid Manag. 2008;4(1):27-33. https://doi.org/10.5055/jom.2008.0005

43. Kairaluoma P, Mattson J, Heikkila P, Pere P, Leidenius M. Perioperative Paravertebral Regional Anaesthesia and Breast Cancer Recurrence. Anticancer Res. 2016;36(1):415-8.

44. Deegan CA, Murray D, Doran P, Ecimovic P, Moriarty DC, Buggy DJ. Effect of anaesthetic technique on oestrogen receptor-negative breast cancer cell function in vitro. Br J Anaesth. 2009;103(5):685-90. https://doi.org/10.1093/bja/ aep261

45. Karmakar MK, Samy W, Li JW, Lee A, Chan WC, Chen PP, et al. Thoracic paravertebral block and its effects on chronic pain and health-related quality of life after modified radical mastectomy. Reg Anesth Pain Med. 2014;39(4):289-98. https:// doi.org/10.1097/aap.0000000000000113

46. Cata JP, Forget P. Paravertebral block with propofol anaesthesia does not improve survival compared with sevoflurane anaesthesia for breast cancer surgery: independent discussion of a randomised controlled trial. Br J Anaesth. 2020;124(1):1924. https://doi.org/10.1016/j.bja.2019.09.039

47. Ishikawa M, Sakamoto A, Ma D. Recurrence of breast cancer after anaesthesia. Lancet. 2020;396(10248):375-6. https://doi. org/10.1016/S0140-6736(20)30488-8 
48. Moris D, Kontos M. Recurrence of breast cancer after anaesthesia. Lancet. 2020;396(10248):376-7. https:/doi. org/10.1016/S0140-6736(20)30489-X

49. Nielsen KC, Melton MS, Gebhard RE, Greengrass RA. Recurrence of breast cancer after anaesthesia. Lancet. 2020;396(10248):376. https://doi.org/10.1016/S0140-6736(20)30487-6

50. Nounou MI, ElAmrawy F, Ahmed N, Abdelraouf K, Goda S, Syed-Sha-Qhattal H. Breast Cancer: Conventional Diagnosis and Treatment Modalities and Recent Patents and Technologies. Breast Cancer (Auckl). 2015;9(Suppl. 2):17-34. https://doi.org/10.4137/bcbcr.s29420

51. Hennigs A, Riedel F, Marmé F, Sinn P, Lindel K, Gondos A, et al. Changes in chemotherapy usage and outcome of early breast cancer patients in the last decade. Breast Cancer Res Treat. 2016;160(3):491-9. https://doi.org/10.1007/s10549-016-4016-4

52. Forget P, Aguirre JA, Bencic I, Borgeat A, Cama A, Condron $\mathrm{C}$, et al. How anesthetic, analgesic and other non-surgical techniques during cancer surgery might affect postoperative oncologic outcomes: A summary of current state of evidence. Cancers (Basel). 2019;11(5):592. https://doi.org/10.3390/ cancers 11050592

53. Buckley A, McQuaid S, Johnson P, Buggy D. Effect of anaesthetic technique on ER positive breast cancer cell apoptosis in the presence of CD56+ NK cells. Ir J Med Sci. 2013;182:S60. Available from: https://www.embase.com/search/results?sub action=viewrecord\&id=L71326324\&from $=$ export 